\title{
KERKORDE EN BELYDENIS
}

- Ds. C. J. Smit

Die verband tussen kerkorde en belydenis is in die Heilige Skrif vasgelê. Eersgenoemde het sy primêre grondslag in die Skrif en laasgenoemde is in sy geheel 'n weerklank van die Skrif (vgl. Bouwman, 1970: 325, 326). Die belydenis stem ooreen met die Skrif. omdat die kerk bloot die Skrif in die belydenis nasê (homologein) om sy geloof tot uitdrukking te bring.

Die openlike belydenisakte 'Jesus is die Christus' is as geloofsakte ' $n$ eksistensiële beslissing wat die mens se ganse bestaan tot in die wortelvesels daarvan raak: "Vlees en bloed het dit nie aan iou openbaar nie, maar my Vader wat in die hemele is" (Mt. 16:17). Die belydenisinhoud is volstrek normatief, omdat dit 'n suiwere weerklank van God se kragdadige Openbaring aangaande sy Seun is. Nêrens word die belydenisakte in die Nuwe Testament as 'n spontane, onverbonde saak - 'n vryswewende aangeleentheid - geteken nie. As geloofsakte is die homologein, wat letterlik 'om dieselfye te sê' beteken, die deurleefde instemming met die Evangelie - en dit word volkome deur laasgenoemde bepaal (Polman, s.j. : 6, 7).

Soos wat die belydenis ' $n$ antwoord op die Woord is, so is die kerkorde ' $n$ bevestiging van dié antwoord. Die belvdenis antwoord on die vraag "wie is Jesus van Nasaret?" in duidelike Skrifterme: "Hy is die Christus, die Seun van die lewende God" (Mt. 16:16). Die kerkorde bevestig hierdie antwoord deur te beklemtoon dat dit slegs Hy is wat heerskanny in en oor sy kerk voer, deur sy Woord en Gees (vgl. Hovius, $1962: 24$ ).

Die kerkorde is beide struktureel en essensieël op die belydenis betrokke (Hovius, 1962 : 24). Die belydenisvorming van die kerk roep vanself na ordevorming : die ordening van die kerklike lewe waarvolgens die kerk in gehoorsaamheid onder die heerskanny van Jesus Christus in ooreenstemming met sy belydenis kan leef. Dit hou in dat die kerkorde én sy bestek én sy norm in die belydenis vind en dat die belydenis sy praktiese konkretisering, struktureel gesien, in die kerkorde het.

Die normering van die kerkorde deur die belydenis dui daarop dat die kerkorde sekondêr gesien moet word ten opsigte van die belydenis: die kerkorde is afhanklik van die kerklike leer, soos wat laasgenoemde uit die Skrif georden is. Dit beteken egter nie, soos Nauta (1971:43) dit sien dat die kerke nie geken word aan hulle kerkorde nie, maar slegs aan hulle belydenis. Hierdie siening is die gevolg van 'n kerkbegrip waarvolgens die kerk 'n gewone gemeenskapskring is wat sy eie reëls in sy ordelike funksionering moet daarstel (Vgl. Nauta, $1971: 9$ ).

Die kerkorde wat in die belydenis gegrond is - waarin die omlyning van die kerkinstituering en -organisasie anker - sal die kerk prakties, uitwendig en vormlik, ooreenstemmend met sy homologia, kenbaar maak (vgl. Hovius, 1962 : 24). Maar die kerkorde is, juis omdat dit ook die belydenis as grondslag het, vir die kerk veel meer as 
die bloot vormlike met die oog op eenvormigheid. Trouens die kerkorde is kennelik die kerklike reëling en die ordening van die nuwe lewe onder heerskappy van Jesus Christus (vgl. Spoelstra, 1981a:6). Omdat die kerke een in belydenis is, moet hulle ook as soveel sigbaar geïnstitueerde openbaringe van die een liggaam van Christus één wees in kerkregering (vgl. Van der Linde, 1980:36). En omdat die kerkorde ' $n$ vrug van die belydenis is, kan die Skrifgehoorsaamheid van die kerke ten opsigte van organisasie en regering aan die kerkorde getoets word. Derhalwe sal die kerke institutief aan die kerkorde geken kan word en die kerke se belydenisinhoud sal prinsipieël aan die kerkorde kenbaar wees.

Omdat die belydenis die kerkorde voorafgaan as uitdrukking van die geloofseenheid in Jesus Christus, is die belydenis en nie die kerkorde nie, die grond waarop die kerke in sinode saamkom. Die kerkorde is wel terdeë die modus quo (wyse) waarop die kerke saamkom om saam te regeer. Byvoorbeeld: die kerke wat een in belydenis is, het op grond daarvan in 1862 in Suid-Afrika saamgekom en op grond van sowel as ooreenkomstig daardie belydenis 'n kerkorde opgestel (Van der Linde, 1977/78:2). Die kerkorde is die definiëring van die Skriftuurlike kerkinstituering, kerkorganisasie en kerkregering, derhalwe word in die kerkorde die wvse waarop die Hoof sy liggaam wil laat funksioneer, gereël. As sodanig is die kerkorde nie die akkoord van kerklike gemeenskap nie, maar die reëling daarvoor (vgl. Nauta, 1971:12,13). Indien die kerkorde die grondslag van die saamlewe van die kerke was, sou die kerkorde gesag in homself gehad het met die gevolglike bindingsmag van 'n wet (vgl. Kuyper 1928/29:1). Ook Rutgers (1880:43) het aangetoon dat die basis waarop die kerkorde kerke in kerkverband betrek, die eenheld in belydenis is. As sodanig is die belydenis die 'gemeenskaplike akkoord' tussen die kerke. Reeds die sinode van Emden (1571) reël deur die kerkorde die wrse waarop al die kerke regeer moet word, omdat hulle éen in beludenis is (vgl. Pont, 1981 : 94: Snoelstra, 1981 b : 4). Daarom bepaal die Emdense Kerkorde (artikels 2, 4, 5) uitdruklik dat die geloofsbelydenis, met ander woorde die eenheid in die leer, die samobindende band is wat almal in gehoorsaamheid aan Jesus Christus bvmekaar hou: "Om de eendrachtigheydt in de Leere tusschen de Nederlandtsche Kercken te bewijzen, heeft het den Broederen goed ghedacht de belijdinghe des Gheloofs der Nederlandtsche Kerchen te onderschrijven..." (Pont, 1981:111). Hieruit blyk die basis, die grond, van die kerke se saamlewe vanaf die reformasie ondubbelsinnig.

Derhalwe is dit nie duidelik dat Spoelstra (198 lb :4) kan konkludeer dat die kerkorde kennelik 'n akkoord van gemeenskap is, "hoewel van 'n ander aard as die belydenis" nie. Die bevoegdheid van die kerkorde op sterkte waarvan gesamentlik sekere sake in die kerkverband hanteer word (Spoelstra, 1967:26), maak myns insiens nog nie daarvan die grond waarop kerke in kerkverband saamkom nie.

In die sinodokratiese (kollegialistiese) kerkregeringsbeskouinge word die gedagte gehuldig dat die kerkorde die "kontrak" is waarop 
die kerk as korporatiewe eenheid rus (Van der Linde, 1965:122). Hiervolgens is dit die kerkorde wat die kerke, nie in kerkverband nie, maar as kerkverband betrek. Die kerkverband mag dan alleen deur 'n kerk opgesê word as die kerkorde daartoe die reg gee. Derhalwe word die kerkorde as akkoord van kerklike gemeenskap beskou, oftewel die fondament waarop die kerk gebou is. Kragtens daardie fondament het die sinode die hoogste gesag, want slegs die sinode kan die kerkorde wysig (ibid:123).

Die bruikbaarheid van die kerkorde het van die reformasie af steeds gerus op die een voorwaarde, naamlik dat die kerke één in belydenis bly deur hulle tesame te onderwerp aan Gods Woord (Rutgers, $1890: 43$ ). Gevolglik is die kerkorde 'n uitdrukking sowel as 'n bevordering van die belydenis én die eenheid... juis deurdat die kerkorde die belydenis en die eenheid veronderstel en vereis. Maar alhoewel die kerkorde 'n konfessionele inslag het. en hoewel dit in die belydenis grond, is die kerkorde nooit deur die Gereformeerde kerke as addissionele of supplementêre belydenisse gesien nie (De Jongh, $1967: 17$ ). Die feit dat die ou kerkorde-ontwerpe dikwels as 'n byvoegsel by die belydenisse gevolg is, moenie tot so 'n opvatting aanleirling gee nie.

Dat die kerkorde nie dieselfde gesag as die belydenis het nie en derhalwe nie uitsluitlik. of $66 \mathrm{k}$. as akknord van kerklike remeenskap kan dien nie, spreek verder uit die verskil tussen die twee wat in hoofsaak in hulle onderskeie doelstellings lê. Dié verskil lê daarin dat die doel van die belvdenis is om die waarheid van Gods Woord in ' $n$ ordelike samevatting (gesismatiseerd) na te snreek; daarteenoor is die doel van die kerkorde om die goeie orde in die kerk van Christus te onderhou. Dit is immers allereers Gods Woord en nie "die goeie orde" nie, wat kerkverband noodsaak en dit eksplisiet eis

Die vervanging van die belydenis as grondslag van die kerke se saamlewe, laat in beginsel 'n nuwe hiërargie ontstaan. Wesenlik word die gesag van Christus dan ingeruil vir die gesag van die 'kornoratiewe struktuur', oftewel die sinnde (Van der Linde. 1965:123).

Die grondbeginsel in die kerkorde - wat met hartstogtelike erns deur Calvyn (1956 :IV, II 4; IV, III, 1, 2, 7, 8, 14; IV, VII, 23; IV, VIII, $1-4,7,8$ ) beklemtoon is - naamlik die alleenheerskappy van die Woord van God, is 'n uitdruklike konfessionele aangeleentheid. Trouens hierdie grondbeginsel funksioneer ook as uitgangspunt van die belydenis (Hovius, 1962:7). Essensiëel word die kerkorde op die belydenis daarin gegrond dat Christus die ewige Koning is wat self deur sy Woord regeer, waarin $\mathrm{Hy}$ sy ordinansies gegee het.

Hierdeur word die essensie van die kerkorde daarop gerig om die alleenheerskappy van Gods Woord te verwerklik en te bewaar en om dus nie menslike wette in te voer en daaraan goddelike gesag te gee nie. Struktureel word die kerkorde op die belydenis daarin gegrond dat die verwerkliking van die alleenheerskappy van Gods Woord deur die ampte of dienste, die kerklike vergaderings of samekomste, die toesig oor die leer, sakramente en seremonies en die kerklike tug, sal geskied. Hierdeur word die strukturele bestek van 
die kerkorde eweneens daarop gerig om die alleenheerskappy van Gods Woord, soos nagesê in die belydenis, te bewaar en te handhaaf téén die 'kanonisering' van menslike wette waardeur die gewetens van God se uitverkore kinders gebind sal word.

Derhalwe is dit ook te begrype dat die Dordtse Kerkorde sy verankerdheid in die belydenis pertinent uitspreek, soos byvoorbeeld in artikels $53-55,61$ en 68 . Volgens Hovius $(1962: 24)$ is juis hierdie deurwade verankerdheid in die belydenis die rede waarom die kerkorde Skrifbewyse by elke artikel mag ontbeer. Hierdie wesensbinding aan die belydenis verbind elkeen wat deel is van die kerk van die Here aan gehoorsaamheid en diensbaarheid aan die Heilige Skrif, waarvolgens alle gesagsbediening in die kerkregering gerig moet word.

Selfs die aspekte wat - kerkordelik gesproke - aan die vryheid van die kerke oorgelaat is, is konfessioneel begrond, in hierdie verband onderskei Voetius uitdruklik tussen die bevele in Gods Woord - die opdragte en instellings van Christus self, die voorbeelde van die apostoliese kerke en alles wat hierby inbegrepe of wettig daaruit afgelei kan word - enersyds, en die reëlings wat die kerk self mag tref tot opbouing van die liggaam van Christus - wat dus nie in stryd is met wat Hy beveel het nie - andersyds (Hovius, 1962 : 11). God se positiewe bepalinge en opdragte vir die kerklike lewe noem hy die jus divinum positivum en God se opdrag, waarvolgens die kerk self toegelaat word om praktiese, institutiewe reëlings volgens plek en tydsomstandighede te formuleer, noem hy die jus divinum permissivum. Sowel die jus divinum positivum as die jus divinum permissivum is gegrond op die belydenis: eersgenoemde in artikel 30 wat bepaal dat die ware kerk regeer moet word "volgens die geestelike bestuurswyse wat ons Here ons geleer het in sy Woord" en laasgenoemde in artikel 32 wat bepaal dat dit "nuttig en goed is dat die regeerders van die kerk onder mekaar sekere ordinansies instel en bevestig tot instandhouding van die liggaam van die kerk" (Nederlandse Geloofsbelydenis, artikel 30, 32).

Om aan te toon hoe die Dordtse Kerkorde in sy geheel op die belydenis gegrond is, gee ek die volgende oorsig:

i Die grondbeginsel van die kerkorde is op die belydenis gegrond, waar Christus se bevoegdheid en mag as Hoof van sy liggaam, byvoorbeeld in Die Nederlandse Geloofsbelydenis (artikels 27, 29, 31-35), eksplisiet tot uitdrukking gebring word.

ii Die dienste, soos uiteengesit in die kerkorde (artikels 2-28, 83), is op Die Nederlandse Geloofsbelydenis gegrond (artikels 3032), waar die onderhawige saak pertinent omlyn word.

iii Die kerkraad en die meerdere vergaderings, soos uiteengesit in die kerkorde (artikels 29-52), is op Die Nederlandse Geloofsbelydenis gegrond, waar die kerkraad duidelik in artikel 30 en die meerdere vergaderings in beginsel in artikel 32 aangewys word.

iv Die leer, sakramente en ander seremonies, soos uiteengesit in die kerkorde (artikels 53-70), is uitdruklik gegrond op Die Nederlandse Geloofsbelydenis (artikels 33-35). 
$v$ Die tug, soos uiteengesit in die kerkorde (artikels $71-81$ ), is pertinent gegrond op Die Nederlandse Geloofsbelydenis (artikel 32 ).

Ten slotte moet hier gewys word op die sogenaamde diskrepansie tussen die Dordtse Kerkorde en die belydenis, wat meermale aangevoer is (vgl. Hovius, 1962:17-19; Polman, s.j.: 24-29). Hierdie 'diskrepansie' word in drie punte saamgevat:

1 Die kerkorde (artikel 29) noem die kerkraad asmede vier ander kerklike vergaderings, terwyl Die Nederlandse Geloofsbelydenis (artikel 30) slegs die kerkraad noem.

Antwoord: Die beginsel van meerdere vergaderings kom duidelik in die Nederlandse Geloofsbelydenis (artikel 32) voor, waar dit om die daarstelling van 'n kerkorde vir al die kerke in kerkverband gaan. Dit moet gesien word in die lig daarvan dat die belydenis die beginsel daarstel, terwyl die kerkorde die beginsel sowel as die differensiëring en die funksionering daarvan formuleer.

ii Die Nederlandse Geloofsbelydenis (artikel 30) noem drie dienste, terwyl die kerkorde (artikel 2) vier dienste noem.

Antwoord: Die bykomende diens van professore aan die Teologiese Skool is nie prinsipieël ' $n$ ander diens nie, maar dit is 'n prinsipieël en praktiese geregverdigde differensiëring van die diens van Woordbedienaar.

iii Die Nederlandse Geloofsbelydenis (artikel 30) reken die diakens tot die kerkraad, terwyl die kerkorde (vgl. artikel 5) deurgaans 'n uitdruklike onderskeid tussen die kerkraad en die diakens maak.

Antwoord: Die belydenis gaan prinsipiëel uit van die eenheid van die dienste, terwyl die kerkorde funksioneel uitgaan van die differensiëring van die dienste.

\section{Terugskouing:}

Die belydenis is norm vir die kerkorde. Maar die kerke word aan sowel die belydenis as die kerkorde geken. Nie die kerkorde nie, maar die belydenis is die "akkoord van kerklike gemeenskap'. Die kerkorde is én essensieël én struktureel op die belydenis gegrond. Selfs die aspekte wat kerkordelik aan die vryheid van die kerke oorgelaat is, is konfessioneel begrond. Die sogenaamde diskrepansie tussen kerkorde en belydenis is verantwoordbaar.

\section{LITERATUUR}

Bouwman, H. 1970 Gereformeerd kerkrecht, d1. 1. Kampen: Kok.

Calvin, J 1956 Institutie of onderwijzing in de christelijke godsdienst, 3 dle., 4 de dr. (Uit Latyn vertaal deur A. Sizoo). Delft: Meinema.

De Jong, P. Y. 1967. The genius of reformed church policy. (In Church order 


\section{In die Skriflig}

and church union, conference papers of the reformed ecumenical synod conference on church order. Glenside).

Hovius, J. 1962 Het verband tussen onze belijdenis en onze kerkorde. Sneek: Weissenbach.

Kuyper, H. H. 182829 College dictaten: Gereformeerd Kerkrecht. (Ongepubliseerde klasaantekeninge)

Nauta, D. 1971 Verklaring van de kerkorde van de Gereformeerde Kerken in Nederland Kampen: Kok.

Polman, A D. R. s.j Onze Nederlandsche Geloofsbelijdenis: verklaard uit het verleden geconfronteerd met de heden, d1. 4. Franeker: Wever.

Pont, A. D. 1981 Die historiese agtergronde van ons kerklike reg. Pretoria en Kaapstad: Haum.

Rutgers, F. L. 1890 De geldigheid van de oude kerkordening der Nederlandsche Gereformeerde Kerken. Amsterdam: Wormser.

Spoelstra, B. 1981a Die verhouding van kerkreg en kerkorde. (Ongepubliseerde gaskollege)

1981b Calvyn se kerkreg en invloed op kerke In Suld-Afrika. In dle Skriflig. 15 (59) : 4-23, September.

1967 Die gesag van meerdere kerkvergaderings. In die Skrifitg, (3) 23-34, Mel-Junie.

Van der Linde, G. F. L. 1980 Kerkreg, d1. 2. (Ongepubliseerde klasdiktaat, Teologiese Skool: PU vir CHO).

1977/78 Die kerkorde van die Gereformeerde Kerk in Suid Afrika. (Ongepubliseerde klasdiktaat. Teologiese Skool: PU. vir CHO).

1965 Die Grondbeginsels van die presbiteriale kerkregeringstelsel. Potchefstroom: Pro Rege. 